\title{
Faktor-faktor yang Mempengaruhi Pengguliran Dana Pinjaman Program Sari Tani di Desa Tuabatan Kecamatan Miomaffo Tengah Kabupaten Timor Tengah Utara
}

\author{
Bryan Adrianus Matonenga ${ }^{\mathrm{a}}$, Werenfridus Taena ${ }^{\mathrm{b}}$ \\ ${ }^{a}$ Fakultas Pertanian, Universitas Timor, TTU-NTT, Indonesia. Email: matonengbryanadrianus@gmail.com \\ ${ }^{b}$ Fakultas Pertanian, Universitas Timor, TTU-NTT, Indonesia. Email: weren_ntt@yahoo.co.id
}

\section{Article Info}

Article history:

Received 2 Februari 2019

Received in revised form 23 Februari 2019

Accepted 8 Maret 2019

https://doi.org/10.32938/ag.v4i2.666

Keywords:

Faktor

Program

Dana Bergulir

$\underline{\text { Sari Tani }}$

\section{Abstrak}

Penelitian ini bertujuan untuk mengetahui faktor-faktor yang mempengaruhi pengguliran dana pinjaman Program Sari Tani di Desa Tuabatan Kecamatan Miomaffo Tengah. Metode penelitian yang dipergunakan adalah metode survei dengan teknik sampling yang digunakan yaitu purposive sampling sebanyak 40 responden. Analisis data yang digunakan adalah analisis deskriptif kualitatif dan analisis logit. Penelitian ini menemukan terdapat 5 kelompok yang mendapat dana awal untuk mengusahakan penggemukan babi dan paronisasi sapi. Hasil penelitian juga menunjukan bahwa penggunaan faktor yang mempengaruhi pengguliran Dana Sari Tani di Desa Tuabatan adalah status keanggotaan sedangkan umur, pendapatan dan komunikasi tidak berpengaruh terhadap pengguliran Dana Sari Tani di Desa Tuabatan.

\section{Pendahuluan}

Pembangunan pertanian diharapkan dapat memberikan kontribusi yang lebih besar dalam rangka mengurangi kesenjangan dan memperluas kesempatan kerja, serta mampu memanfaatkan peluang ekonomi yang terjadi sebagai dampak dari globalisasi dan liberalisasi ekonomi dunia. Program pembangunan yang berkualitas dan handal, dengan memiliki tujuan kemandirian, profesionalitas, berjiwa wirausaha (entrepreneurship), berdedikasi, etos kerja yang tinggi, disiplin dan moral yang luhur serta berwawasan global, membuat petani dan pelaku usaha pertanian lainnya akan mampu membangun usahatani yang berdaya guna dan berdaya saing (Muhammad, 2008)

Dalam pelaksanaan pengguliran dana program Sari Tani, diduga adanya pengaruh dari umur, pendapatan, komunikasi, dan status anggota berpengaruh atau tidak berpengaruh terhadap pengguliran dana. Faktor-faktor pengguliran dana seperti umur, pendapatan, komunikasi, dan status anggota yang dimiliki belum dikelola secara maksimal, sehingga dapat menentukan tingkat pengguliran dana. Metode analisis Regresi Logit digunakan untuk mengatahui secara pasti pengaruh dari variabelvariabel tersebut di atas. Program Sari Tani adalah sebuah gerakan cinta petani yang memiliki empat tujuan dasar yakni sebagai upaya penanggulangan kemiskinan masyarakat desa, sebagai upaya pengembangan ekonomi produktif melalui pemberian bantuan dana bergulir sebagai modal usaha masyarakat miskin, sebagai strategi untuk mengembangkan produk unggulan kabupaten dan sebagai upaya untuk menguatkan kapasitas fiskal desa. Pemerintah kabupaten TTU memiliki tekat mensejahterakan masyarakat dengan menggulirkan dana sebesar Rp. 300.000.000,- per desa untuk kegiatan pemberdayaan masyarakat melalui kelompok tani atau usaha kecil yang melakukan berbagai kegiatan ekonomi produktif (BPS Kab. TTU, 2017).

\section{Metode}

Penelitian dilaksanakan di Desa Tuabatan Kecamatan Miomafo Tengah Kabupaten Timor Tengah Utara pada bulan Mei 2017 sampai selesai. Metode yang digunakan pada masyarakat di Desa Tuabatan Kecamatan Miomafo Tengah, adalah dilakukan secara purposive sampling yaitu teknik pengambilan sampel dengan pertimbangan tertentu. Memilih beberapa masyarakat yang mendapatkan akses dana Program Sari Tani sebanyak 20 orang, dan yang belum mengakses Dana Program Sari Tani sebanyak 20 orang sehingga total responden dalam penelitian adalah 40 orang.

Untuk mengetahui gambaran program Sari Tani dilakukan analisis deskriptif. Sedangkan untuk mengetahui pengaruh masing-masing faktor pengguliran dana pinjaman Program Sari Tani digunakan analisis Regresi Logit dan penelitian ini merupakan hasil eksperimen faktor-faktor yang mempengaruhi pengguliran dana pinjaman program Sari Tani.

\section{Hasil dan Pembahasan}

\subsection{Analisis Regresi Logit}

Analisis yang digunakan pada penelitian ini adalah model regresi nonlinear yang menghasilkan sebuah persamaan dimana variabel independen bersifat kategorial.

\section{Uji Signifikan}

Tabel "Omnibus Tests of Model Coefficients" dari hasil SPSS model Regres Binary logistik digunakan untuk melihat hasil pengujian secara simultan pengaruh variabel bebas. Berdasarkan tabel di atas diperoleh nilai Chi-square 55.452 dengan nilai Signifikan Model sebesar 0,000 < 0,05 ( $\alpha$ 5\%) maka H1 ditolak pada tingkat signifikan 5\% sehingga dapat disimpulkan bahwa variabel bebas $(\mathrm{X})$ : umur, pendapatan, komunikasi dan status anggota secara bersama sama berpengaruh terhadap variabel terikat pengguliran dana tersebut.

\section{Persentase Ketepatan Klasifikasi (Percentage Correct)}

Presentase ketepatan model dalam mengklasifikasikan observasi adalah $50 \%$. Seluruh observasi telah tepat diklasifikasikan dalam model regresi binary logistik. Jumlah observasi yang tepat pengklasifikasiannya dapat dilihat pada diagonal utama.

Omnibus Tests of Model Coefficients

\begin{tabular}{llccc} 
& & Chi-square & Df & Sig. \\
\hline Step 1 & Step & 55.452 & 4 & .000 \\
& Block & 55.452 & 4 & .000 \\
& Model & 55.452 & 4 & .000 \\
\hline
\end{tabular}

Classification Table ${ }^{\mathrm{a}, \mathrm{b}}$

\begin{tabular}{|c|c|c|c|c|}
\hline \multirow{3}{*}{\multicolumn{2}{|c|}{ Observed }} & \multicolumn{3}{|c|}{ Predicted } \\
\hline & & \multicolumn{2}{|c|}{ Stpinjaman } & \multirow{2}{*}{$\begin{array}{c}\text { Percentage } \\
\text { Correct }\end{array}$} \\
\hline & & 0 & 1 & \\
\hline \multirow[t]{2}{*}{ Stpinjaman } & 0 & 0 & 20 & .0 \\
\hline & 1 & 0 & 20 & 100.0 \\
\hline \multicolumn{2}{|c|}{ Overall Percentage } & & & 50.0 \\
\hline
\end{tabular}

\section{Uji Parsial dan Pembentukan Model}

Tabel "Variables not in the Equation" dapat dilihat variabel yang tidak berpengaruh signifikan dan dimasukan ke dalam model logistik di bawah:

$$
\operatorname{Ln}\left(\frac{P_{i}}{1-P_{i}}\right)=\beta_{0}+\beta_{1} X_{1}+\beta_{2} X_{2}+\beta_{3} X_{3}+\beta_{4} X_{4}+e .
$$

Hasil pengolahan program SPSS, secara parsial variabel penjelas yakni, umur, pendidikan dan komunikasi secara statistik tidak berpengaruh secara signifikan. Hal ini terlihat pada nilai masing-masing variabel penjelas lebih besar dari $0.05(\alpha=5 \%)$. Secara statistik bukan berarti pengaruhnya tidak ada, melainkan ada pengaruhnya hanya sangat kecil, dapat dilihat pada tabel diatas. Variables not in the Equation ${ }^{\text {a }}$

\begin{tabular}{|c|c|c|c|c|c|}
\hline \multirow{5}{*}{ Step 0} & \multirow{5}{*}{ Variables } & & Score & Df & Sig. \\
\hline & & Umur & .834 & 1 & .361 \\
\hline & & Pendapatan & 1.087 & 1 & .297 \\
\hline & & Komunikasi & .016 & 1 & .900 \\
\hline & & Stanggota & 40.000 & 1 & .000 \\
\hline
\end{tabular}

Hasil output persamaan model logistic sebagai berikut:

$$
\begin{aligned}
& \operatorname{Ln}\left(\frac{P_{i}}{1-P_{i}}\right)=\beta_{0}+\beta_{1} X_{1}+\beta_{2} X_{2}+\beta_{3} X_{3}+\beta_{4} X_{4}+e \ldots \ldots \ldots \ldots \ldots \ldots \\
& \operatorname{Ln}\left(\frac{P_{i}}{1-P_{i}}\right)=0,00+0,834 \mathrm{U}+1,087 \mathrm{P}+0,016 \mathrm{Ko}+40 \text { Stang }+e \ldots .
\end{aligned}
$$


Interpretasi dari Persamaan Model logistik sebagai berikut:

\section{Umur $\left(\mathbf{X}_{1}\right)$}

Koefisien regresi logit $\mathbf{X}_{1}$ (umur) bernilai sebesar 0,834 dengan sig 0,361 artinya: setiap penambahan umur seseorang sebesar 1 tahun maka tingkat pelaksanaan tugas dan kewajiban sesorang akan meningkat karena semakin bertambah usia produktif maka semakin bertambah pula daya pikir dalam memecakan suatu persoalan. Joka (2017), mengungkapkan bahwa faktor usia petani berpengaruh secara simultan (bersama-sama) terhadap tingkat pendapatan usahatani padi sawah di Kabupaten Kupang tahun 2014

\section{Total pendapatan $\left(\mathbf{X}_{2}\right)$}

Koefisien regresi logit $\mathrm{X}_{2}$ (total pendapatan) bernilai sebesar 1,087 dengan sig sebesar 0,297 artinya: setiap penambahan total pendapatan seseorang dari gaji yang diperoleh setimpal dengan kebutuhan dalam keluarga. Pendapatan responden dalam penelitian ini yakni lima ratus ribu sampai satu juta lima ratus ribu rupiah.

Hasil penelitian ini sejalan dengan penelitian Tohir (1991) menyatakan bahwa bertambahnya pendapatan maka bertambah pula kebutuhan dalam keluarga sehingga petani mencari pekerjaan tambahan.

\section{Komunikasi $\left(\mathbf{X}_{3}\right)$}

Koefisien regresi logit $\mathrm{X}_{3}$ (Komunikasi) bernilai sebesar 0,016 dengan sig sebesar 0,9 artinya: bahwa komunikasi tidak berpengaruh terhadap pengguliran Dana Sari Tani, alasannya berkurangnya tingkat komunikasi seseorang maka berkurangnya arus informasi terhadap Program Sari Tani dan juga akan berpengaruh terhadap kelompok peminjam Dana Sari Tani dalam mengelolah dana tersebut secara bertanggung jawab.

Hasil penelitian ini sejalan dengan penelitian Sunarti (2003), menunjukkan bahwa komunikasi yang intensif antara sesama warga masyarakat, antara warga masyarakat dengan pimpinannya serta antara sistem sosial di dalam masyarakat dengan sistem diluarnya mampu meningkatkan peran dan partisipasi dalam kelompok.

\section{Status anggota $\left(\mathbf{X}_{4}\right)$}

Koefisien regresi logit $\mathrm{X}_{4}$ (status anggota) bernilai sebesar 40 dengan sig 0,000 artinya: bahwa status keanggotaan berpengaruh nyata pada pengguliran Dana Sari Tani, alasannya status anggota sari tani sangat penting untuk diketahui karena setiap Dana Sari Tani yang diterima akan dikembalikan untuk digulirkan kepada orang lain.Status anggota sangat penting dalam persetujuan dana pinjaman. Hal ini ditunjukkan dengan setiap anggota kelompok sari tani yang disetujui untuk memperoleh dana pinjaman.

Hasil penelitian ini sejalan dengan penelitian Wirutomo (1981) mengemukakan pendapat David Berry bahwa dalam status/peran yang berhubungan dengan pekerjaan, seseorang diharapkan menjalankan kewajibankewajibannya yang berhubungan dengan peranan yang dipegangnya.

\section{Simpulan}

Program Sari Tani merupakan salah satu program yang dicanangkan oleh pemerintah Kabupaten Timor Tengah Utara (TTU) yang memiliki tekad untuk mensejahterakan masyarakat dengan bentuk bantuan yaitu pengguliran dana pinjaman pada tingkat masyarakat kecil untuk kegiatan pemberdayaan masyarakat Timor Tengah Utara. Dana pinjaman Sari Tani di Desa Tuabatan di mulai dengan pengguliran dana pada kelompok tani dengan rincian 2 kelompok penggemukan sapi dan 3 kelompok penggemukan babi. Secara parsial status anggota berpengaruh signifikan terhadap persetujuan dana pinjaman. secara simulatan pengaruh variabel bebas, diperoleh nilai Chi-square 55.452 dengan nilai Signifikansi model sebesar $0,000<0,05(\alpha 5 \%)$ maka H1 ditolak pada tingkat signifikan $5 \%$ sehingga dapat disimpulkan bahwa variabel bebas (X) : umur, pendapatan, komunikasi dan status anggota secara bersama-sama berpengaruh terhadap variabel terikat Pengguliran Dana tersebut.

\section{Pustaka}

BPS TTU. TTU Dalam Angka 2017. Tentang Pedoman Pelaksanaan Program Desa Mandiri Cinta Petani. Kabupaten Timor Tengah Utara.

Gujarati, 2003. Ekonometri Dasar. Terjemahan: Sumarno Zain, Jakarta: Erlangga.

Joka, Umbu. 2017. Dampak Program Pengembangan Usaha Agribisnis Pedesaan (PUAP) Terhadap Adopsi Teknologi dan Pendapatan Petani Padi di Kabupaten Kupang Provinsi NTT. (http://repository.ipb.ac.id/handle/123456789/87908, Diakses pada tanggal 27 September 2017)

Muhammad, Bansir. 2008. Analisis Pengaruh faktor-faktor yang mempengaruhi kinerja penyuluhan pertanian di Kabupaten Bulungan Kalimantan Timur . (http://repository.sb.ipb.ac.id/2061/, Diakses pada tanggal 27 September 2017)

Pemerintah Desa Tuabatan. 2017. Profil Desa Tuabatan. Pemerintah Desa Tuabatan.
Pemerintah Kab. TTU. 2012. Profil Sari Tani, Tentang Petunjuk Teknis Perubahan Peraturan Bupati Timor Tengah Utara Nomor 4. Kabupaten TTU.

Sunarti. 2003. Partisipasi Masyarakat dalam Pembangunan Perumahan secara Kelompok. Jurnal Tata Loka. Semarang: Planologi UNDIP

Tohir. 1991. Usahatani, Reinika: Jakarta.

Wirutomo, 1981. Sosialisasi Dalam Keluarga Indonesia; Fisip UI, Jakarta, 1994. 